\title{
SYNTHESIS, CHARACTERIZATION AND CYTOTOXIC ANTIBACTERIAL ACTIVITY OF Ru(II) ETHOXYSALAL THIOSEMICARBAZONE COMPLEXES
}

\author{
K. Sampath ${ }^{1, *}$, R. Ashokkumar ${ }^{1}$, A. Venkatachalam ${ }^{2}$ \\ and M. Shanmugaprakash ${ }^{3}$ \\ ${ }^{1}$ Department of Science and Humanities, Chemistry Division, Kumaraguru College of \\ Technology, Coimbatore -641049, Tamil Nadu, India. \\ ${ }^{2}$ Center for Supramolecular Chemistry and Catalysis, Shanghai University, \\ Shanghai-200444, China. \\ ${ }^{3}$ Department of Biotechnology, Kumaraguru College of Technology, \\ Coimbatore-641049, Tamil Nadu, India. \\ *E-mail : sampathchemistry@ gmail.com
}

\begin{abstract}
A set of complexes, $\left[\mathrm{RuCl}(\mathrm{CO})(\mathrm{B})\left(\mathrm{EPh}_{3}\right) \mathrm{L}\right]$ (where $\mathrm{E}=\mathrm{P} / \mathrm{As} ; \mathrm{B}=\mathrm{PPh}_{3} / \mathrm{AsPh}_{3} / \mathrm{py} ; \mathrm{L}=$ ligand), of ruthenium have been synthesized by solution method. The structure of the ruthenium(II) complexes were determined by microanalytical techniques and spectral techniques (CHNS, Infrared, ultraviolet-visible and NMR spectroscopic techniques). FT-IR results reveal that thiosemicarbazone is coordinated to $\mathrm{Ru}(\mathrm{II})$ via ONS. In addition, the structure of the compounds, thiosemicarbazone ligand and complexes, was confirmed by Nuclear Magnetic Resonance Spectroscopy. Further, the synthesized ligand and its complexes were analyzed against human pathogens.

Keywords: Ethoxysalicylaldehyde, Thiosemicarbazide, Antibacterial activity, Ruthenium(II).
\end{abstract}

(C) RASĀYAN. All rights reserved

\section{INTRODUCTION}

The synthesis of coordination complexes with mixed ligands have attracted widespread attention in the recent years due to their extensive biological properties i.e., antimalarial, antibacterial, anticancer, etc. ${ }^{1}$ In the transition metals, noble group elements have shown significant contribution in the field of pharmacology. Among the noble group elements, ruthenium possesses variable oxidation states. Moreover, the ability to resemble the binding properties towards biological significance. ${ }^{2}$ Schiff bases bearing $\mathrm{N}, \mathrm{O}$ and $\mathrm{S}$ donor atoms are a kind of versatile ligands in coordination chemistry. Thiosemicarbazones are a class of ligands have emerged as relatively non-innocent ligands with varied biological properties. ${ }^{3}$ Thiosemicarbazone complexes derived from salicylaldehyde derivatives containing $\mathrm{N}_{2} \mathrm{O}, \mathrm{N}_{2} \mathrm{~S}$, or ONS donor atoms have shown enormous impact in the pharmacology. ${ }^{4}$ In this present context, we have synthesized three ruthenium. These complexes were subjected to antibacterial activity.

\section{EXPERIMENTAL}

The solvents and chemicals were used are reagent grade and AR grade. The ethoxy derivative of salal thiosemicarbazone ligand was synthesized following a published procedure. ${ }^{5}$ The metal precursors, $\left.\left[\mathrm{RuHCl}(\mathrm{CO})(\mathrm{py})\left(\mathrm{PPh}_{3}\right)_{2}\right],\left[\mathrm{RuHCl}(\mathrm{CO}) \mathrm{AsPh}_{3}\right)_{3}\right]$ and $\left[\mathrm{RuHCl}(\mathrm{CO})\left(\mathrm{PPh}_{3}\right)_{3}\right]$, were synthesized by reported procedure. $^{6-8}$ In a Vario EL III CHNS analyzer, microanalysis (elemental analysis) of the samples were performed. The Infrared spectrum and UV-Visible spectrum in DMSO solution of the samples were recorded in the range 4000-400 $\mathrm{cm}^{-1}$ and spectrophotometer 2202 in the range 800-200 $\mathrm{nm}$, respectively.In a Bruker AV III $500 \mathrm{MHz}$ instrument, the ${ }^{1} \mathrm{H}$ NMR and ${ }^{13 \mathrm{C}} \mathrm{NMR}$ spectra were recorded

Rasayan J. Chem., 12(1), 257-261(2019)

http://dx.doi.org/10.31788/RJC.2019.1214099

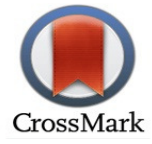


RASĀYAN J. Chem.

Vol. 12 | No. 1 | 257 - 261| January - March | 2019

using an internal reference (TMS). Similarly, ${ }^{31} \mathrm{P}$ NMR spectra were also recorded using orthophosphoric acid.

\section{Synthesis of Ligand}

The 1: the 1-mole ratio of 3-ethoxysalicylaldehyde in ethanol and thiosemicarbazide in methanol were added with continuous stirring to over a period of $1 \mathrm{~h}$. The white colored precipitate was formed, filtered the white colored precipitate. Using TLC, the purity of the formed precipitate was checked.

\section{Synthesis of Ligand : Ruthenium Complexes}

The metal precursors $(0.5 \mathrm{mmol})$ in benzene was slowly added with stirring to a solution of ligand $(0.5$ $\mathrm{mmol}$ ) in methanol and then refluxed for about $6 \mathrm{~h}$. The resulted color solution was kept aside and formed precipitate is filtered off and subjected to purification by TLC.

\section{Antibacterial Activity}

The standard agar diffusion method was used to evaluate the cytotoxic activity of the thiosemicarbazone ligand and the complexes against bacteria. ${ }^{2}$ The data were collected as triplicate runs.

\section{Structure of the Complexes}

\section{RESULTS AND DISCUSSION}

Table-1 gives the results of analytical data and Table-2, 3 and 4 shows spectroscopic data (ligand \& complexes)which reveals that a 1:1 metal-ligand stoichiometry was found. The synthesized complexes are stable in the environment. The synthesis and the proposed structure of the complexes are shown in Scheme-1.<smiles>CCOc1cccc(/C=N/NC(N)=S)c1O</smiles>
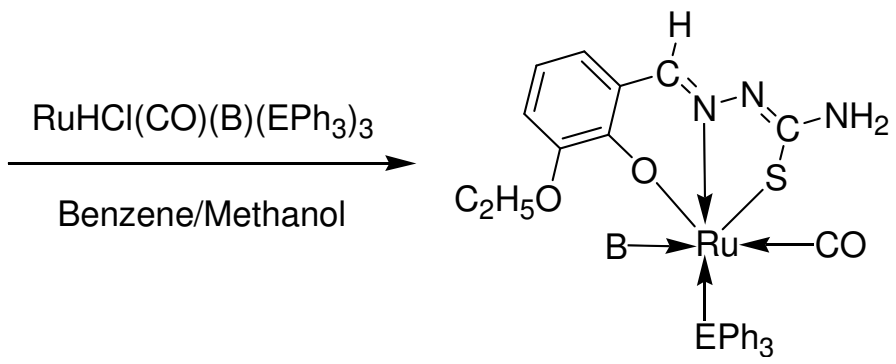

$\mathrm{E}=\mathrm{P} / \mathrm{As} ; \mathrm{B}=\mathrm{PPh}_{3} / \mathrm{AsPh}_{3} / \mathrm{py}$

Scheme-1 :Synthesis of Ruthenium(II) Complexes

Table-1: Analytical Data

\begin{tabular}{c|c|c|c|c|c|c}
\hline \multirow{2}{*}{$\begin{array}{c}\text { Ligand and } \\
\text { Complexes }\end{array}$} & \multirow{2}{*}{ Color } & \multirow{2}{*}{$\begin{array}{c}\text { M.Pt, } \\
{ }^{\circ} \mathrm{C}\end{array}$} & \multicolumn{4}{|c}{ Elemental Analysis Calculated (Found) \% } \\
\cline { 4 - 7 } & & $\mathrm{C}$ & $\mathrm{H}$ & $\mathrm{N}$ & $\mathrm{S}$ \\
\hline Ligand & White & 260 & $50.19(49.85)$ & $5.48(5.72)$ & $17.56(17.68)$ & $13.40(12.98)$ \\
\hline$\left[\mathrm{Ru}(\mathrm{CO})\left(\mathrm{PPh}_{3}\right)_{2} \mathrm{~L}\right]$ & Brown & 298 & $63.36(63.38)$ & $4.64(5.03)$ & $4.72(5.11)$ & $3.60(3.65)$ \\
\hline$\left[\mathrm{Ru}(\mathrm{CO})\left(\mathrm{AsPh}_{3}\right)_{2} \mathrm{~L}\right]$ & Red & 290 & $57.67(57.77)$ & $4.22(4.28)$ & $4.29(3.99)$ & $3.28(3.91)$ \\
\hline$\left[\mathrm{Ru}(\mathrm{CO})(\mathrm{py})\left(\mathrm{PPh}_{3}\right) \mathrm{L}\right.$ & Yellow & 294 & $57.70(57.81)$ & $4.41(4.41)$ & $7.92(8.02)$ & $4.53(4.76)$ \\
\hline
\end{tabular}

\section{IR Spectra}

IR spectroscopy is an important analytical technique in order to determine the coordination mode of the metal atom. The most important IR frequencies of the respective vibrations are tabulated in Table- 2 . The azomethine frequency of the complexes is observed at $1603-1611 \mathrm{~cm}^{-1}$ which was shifted to a lower frequency than the free ligand at $1620 \mathrm{~cm}^{-1}$. It confirms the coordination of the ligand to ruthenium via N. ${ }^{9}$ The $v(\mathrm{C}-\mathrm{S})$ vibrations assigned to $898 \mathrm{~cm}^{-1}$ in the free ligand was shifted to lower vibrations at $765-$ $783 \mathrm{~cm}^{-1}$ ascribed to thiol nature of the ligand followed by coordination through the deprotonated sulfur. ${ }^{10}$ The band observed at $1213 \mathrm{~cm}^{-1}$ is assigned to phenolic $\mathrm{OH}$ group. In complexes, it was disappeared and 
RASĀYAN J. Chem.

Vol. 12 | No. 1 | 257 - 261| January - March | 2019

a new band appeared at $1237-1249 \mathrm{~cm}^{-1}$ which reveals the other coordination mode through oxygen. ${ }^{11}$ Further, in all the complexes studied the band at $1949-1963 \mathrm{~cm}^{-1}$ attributed to $v(\mathrm{C} \equiv \mathrm{O}) .{ }^{12}$ Overall, the free ligand is coordinated to ruthenium atom via ONS.

Table-2: FT-IR and Electronic Spectral Data

\begin{tabular}{c|c|c|c|c|c|c}
\hline \multirow{2}{*}{$\begin{array}{c}\text { Ligand and } \\
\text { Complexes }\end{array}$} & \multicolumn{5}{|c|}{ FT-IR, $\mathrm{cm}^{-1}$} & \multirow{2}{*}{ UV-vis, $\lambda_{\max }(\mathrm{nm})$} \\
\cline { 2 - 6 } & $v(\mathrm{C}=\mathrm{N})$ & $v(\mathrm{C}-\mathrm{S})$ & $v(\mathrm{Ph}-\mathrm{OH})$ & $v(\mathrm{Ph}-\mathrm{CO})$ & $v(\mathrm{C} \equiv \mathrm{O})$ & \\
\hline Ligand & 1620 & 898 & 1213 & - & - & 301,368 \\
\hline$\left[\mathrm{Ru}(\mathrm{CO})\left(\mathrm{PPh}_{3}\right)_{2} \mathrm{~L}\right]$ & 1603 & 765 & - & 1246 & 1955 & $309,369,408$ \\
\hline$\left[\mathrm{Ru}(\mathrm{CO})\left(\mathrm{AsPh}_{3}\right)_{2} \mathrm{~L}\right]$ & 1611 & 783 & - & 1237 & 1949 & $308,370,410$ \\
\hline$\left[\mathrm{Ru}(\mathrm{CO})(\mathrm{py})\left(\mathrm{PPh}_{3}\right) \mathrm{L}\right]$ & 1609 & 774 & - & 1249 & 1963 & $309,371,411$ \\
\hline
\end{tabular}

\section{Electronic Spectra}

The UV-Visible spectral data were recorded in DMSO solvent and are tabulated in Table-2. The two bands of the ligand at $301 \mathrm{~nm}$ and $368 \mathrm{~nm}$ is assigned $\pi \rightarrow \pi^{*}$ and $\mathrm{n} \rightarrow \pi^{*}$ transitions. The thiosemicarbazone ligand bands were shifted to higher wavelength in complexes spectrum at 308-309 nm, $369-371 \mathrm{~nm}$ and a new band at 408-411 nm are assigned to charge transfer transitions. This confirms the coordination of thiosemicarbazone ligand to the ruthenium atom. ${ }^{13}$ The electronic spectral pattern of the synthesized complexes are similar to reported ruthenium(II) complexes. ${ }^{10}$

\section{NMR Spectra}

In order to confirm the binding mode of the thiosemicarbazone ligand to the ruthenium atom, the various NMR spectra were recorded in DMSO- $\mathrm{d}_{6}$. The chemical shift values of the compounds are listed in Table3 and 4. The proton spectrum of the ligand shows a singlet at $\delta 9.0$ due to phenolic $\mathrm{OH}$ proton.In complexes, it was disappeared which confirms the coordination through oxygen. ${ }^{14}$ The azomethine proton of the ligand was observed as a singlet at $\delta 11.3$ in the free thiosemicarbazone ligand which was downfield in the spectra of the complexes at $\delta$ 11.5-11.8 ascribed the other coordination through azomethine N.$^{15}$ The aromatic protons of the ligand and the complexes were appeared as multiplet in the range $\delta$ 6.6-8.6. The other methyl and methylene protons were showed at $\delta 1.3$ and $\delta$ 3.3-3.5 respectively.

The aromatic carbon signals of the thiosemicarbazone ligand and its complexes showed in the region $\delta$ 110-139. The signal of the azomethine carbon in the ligand was detected at $\delta 147$, downfield of this signal in the complexes at $\delta 141-145$ supports the coordination through azomethine carbon. ${ }^{16}$ The signal at $\delta 178$ corresponds to $\mathrm{C}=\mathrm{S}$ of the free thiosemicarbazone ligand. It was disappeared in the complexes spectrum and new signal found at $\delta 169-172$ confirms the coordination of sulphur. ${ }^{17}$ In all the complexes signal of the $\mathrm{C} \equiv \mathrm{O}$ was observed at $\delta 192-196$. The other carbon signals in the ligand and complexes due to methyl and methylene groups were displayed at $\delta 15-17$, and $\delta 59-64$, respectively.

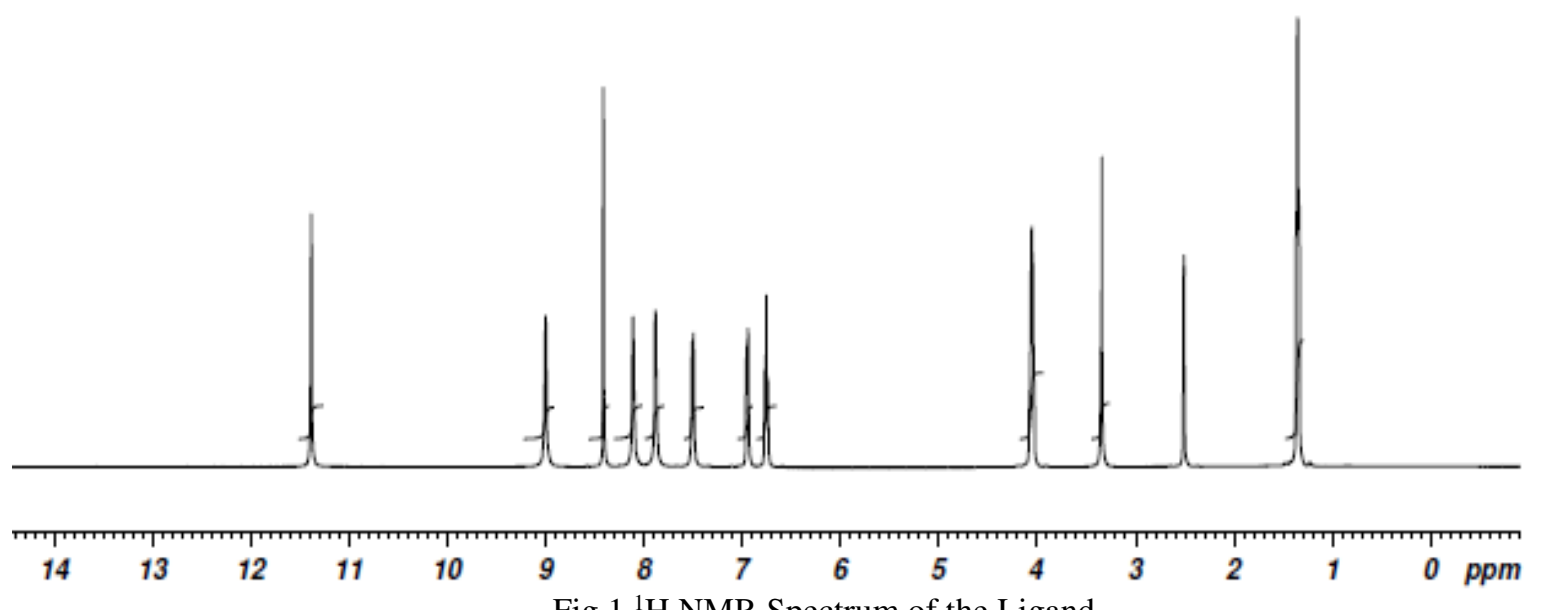

Fig. $1{ }^{1} \mathrm{H}$ NMR Spectrum of the Ligand 
RASĀYAN J. Chem.

Vol. 12 | No. 1 |257 - 261| January - March | 2019

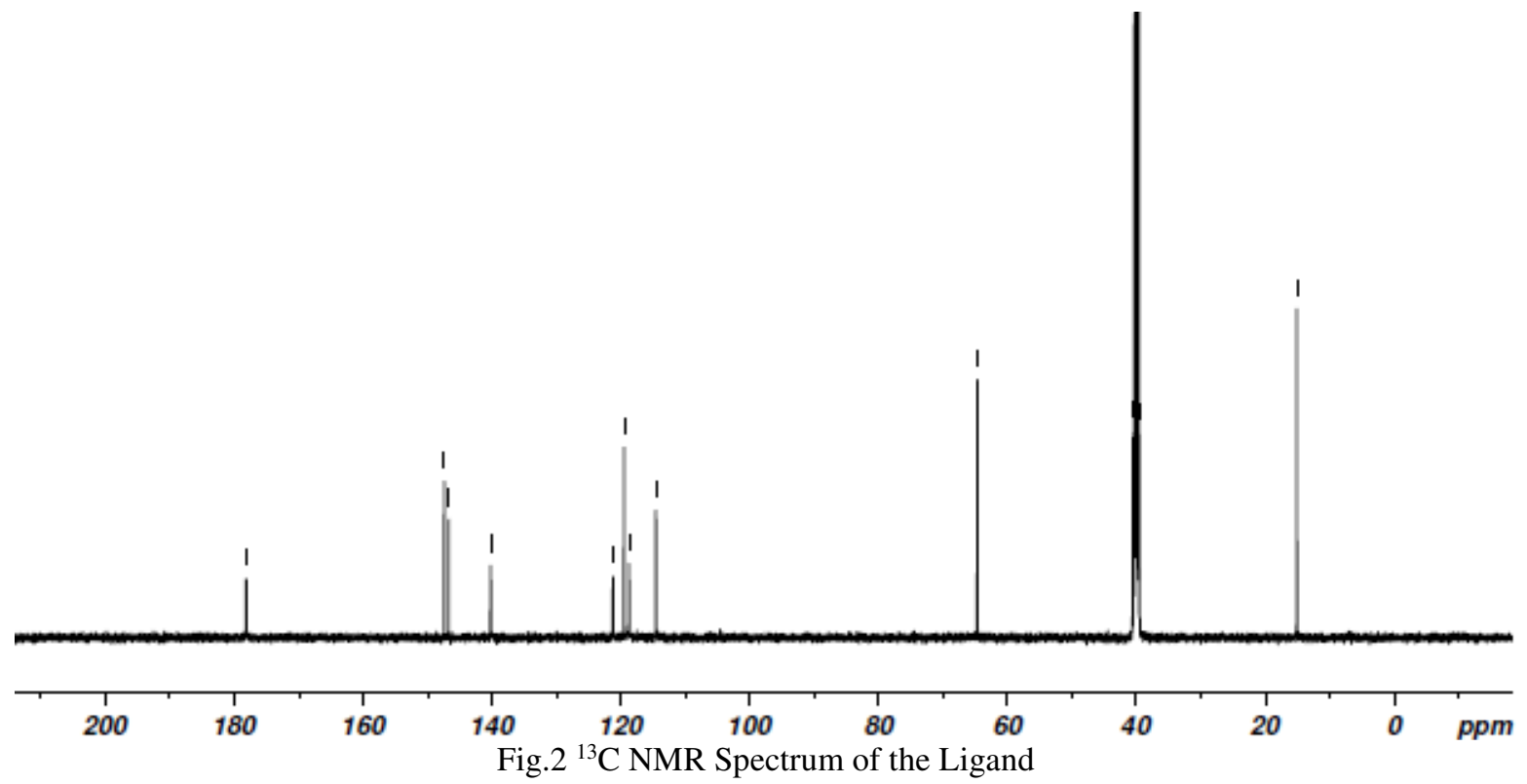

The ${ }^{13} \mathrm{P}$ NMR spectrum of the complexes, $\left[\mathrm{Ru}(\mathrm{CO})(\mathrm{py})\left(\mathrm{PPh}_{3}\right) \mathrm{L}\right]$ and $\left[\mathrm{Ru}(\mathrm{CO})\left(\mathrm{PPh}_{3}\right)_{2} \mathrm{~L}\right]$, showed a signal at $\delta 35.2$, and $\delta 36.3$, respectively, due to the presence of $\mathrm{PPh}_{3}$ (triphenylphosphine group). The NMR spectral analysis confirms the coordination of thiosemicarbazone ligand to the ruthenium atom.

Table-3: ${ }^{1} \mathrm{H}$ and ${ }^{31} \mathrm{P}$ NMR Data

\begin{tabular}{c|c|c|c|c|c|c}
\hline \multirow{2}{*}{ Ligand and Complexes } & \multicolumn{5}{|c|}{$\mathrm{H}$ NMR data, $\delta$} & ${ }^{31} \mathrm{P} \mathrm{NMR} \mathrm{Data,} \delta$ \\
\cline { 2 - 7 } & $\mathrm{Ph}-\mathrm{OH}$ & $\mathrm{HC}=\mathrm{N}$ & Aromatic & $\mathrm{CH}_{2}$ & $\mathrm{CH}_{3}$ & $\mathrm{PPh}_{3}$ \\
\hline Ligand & 9.0 & 11.3 & $6.7-8.4$ & 3.3 & 1.3 & - \\
\hline$\left[\mathrm{Ru}(\mathrm{CO})\left(\mathrm{PPh}_{3}\right)_{2} \mathrm{~L}\right]$ & - & 11.5 & $6.6-8.4$ & 3.4 & 1.3 & 36.3 \\
\hline$\left[\mathrm{Ru}(\mathrm{CO})\left(\mathrm{AsPh}_{3}\right)_{2} \mathrm{~L}\right]$ & - & 11.8 & $6.8-8.6$ & 3.4 & 1.3 & - \\
\hline$\left[\mathrm{Ru}(\mathrm{CO})(\mathrm{py})\left(\mathrm{PPh}_{3}\right) \mathrm{L}\right]$ & - & 11.6 & $6.6-8.5$ & 3.5 & 1.3 & 35.2 \\
\hline
\end{tabular}

Table-4: ${ }^{13} \mathrm{C}$ NMR data

\begin{tabular}{c|c|c|c|c|c|c|c}
\hline Ligand and Complexes & Aromatic Carbon & $\mathrm{C}=\mathrm{N}$ imine & $\mathrm{C}=\mathrm{S}$ & $\mathrm{C}-\mathrm{S}$ & $\mathrm{C} \equiv \mathrm{O}$ & $\mathrm{CH}_{2}$ & $\mathrm{CH}_{3}$ \\
\hline Ligand & $114-146$ & 147 & 178 & - & - & 64 & 15 \\
\hline$\left[\mathrm{Ru}(\mathrm{CO})\left(\mathrm{PPh}_{3}\right)_{2} \mathrm{~L}\right]$ & $110-135$ & 143 & - & 171 & 194 & 60 & 16 \\
\hline$\left[\mathrm{Ru}(\mathrm{CO})\left(\mathrm{AsPh}_{3}\right)_{2} \mathrm{~L}\right]$ & $120-139$ & 145 & - & 169 & 192 & 62 & 15 \\
\hline$\left[\mathrm{Ru}(\mathrm{CO})(\mathrm{py})\left(\mathrm{PPh}_{3}\right) \mathrm{L}\right]$ & $119-137$ & 141 & - & 172 & 196 & 59 & 17 \\
\hline
\end{tabular}

\section{Antibacterial Activity}

To evaluate the cytotoxic activity, it is considered to study the antimicrobial activity. The results of the antibacterial activity are tabulated in Table-5.

Table-5: Antibacterial Activity

\begin{tabular}{c|c|c}
\hline \multirow{2}{*}{ Ligand and Complexes } & \multicolumn{2}{|c}{ The diameter of Inhibition Zone $(\mathrm{mm})$} \\
\cline { 2 - 3 } & S. aureus & E. coli \\
\hline Ligand & 13 & 16 \\
\hline$\left[\mathrm{Ru}(\mathrm{CO})\left(\mathrm{PPh}_{3}\right)_{2} \mathrm{~L}\right]$ & 19 & 22 \\
\hline$\left[\mathrm{Ru}(\mathrm{CO})\left(\mathrm{AsPh}_{3}\right)_{2} \mathrm{~L}\right]$ & 18 & 19 \\
\hline$\left[\mathrm{Ru}(\mathrm{CO})(\mathrm{py})\left(\mathrm{PPh}_{3}\right) \mathrm{L}\right]$ & 21 & 24 \\
\hline Ciprofloxacin & 24 & 27 \\
\hline DMSO & \multicolumn{2}{|c}{ No activity } \\
\hline
\end{tabular}


RASĀYAN J. Chem.

Vol. 12 | No. 1 | 257 - 261| January - March | 2019

The ligand showed significant zone inhibition data against Bacteria. The zone inhibition data of the complexes were higher than that of ligand. It confirms that the cytotoxicity can be increased by the coordination of the free thiosemicarbazone ligand to ruthenium atom. ${ }^{18}$ Though the complexes showed considerable antibacterial activity none of them could reach the potential of the standard drug.

\section{CONCLUSION}

In this present study, we have synthesized three ruthenium(II) complexes of 3-ethoxy salicylaldehyde thiosemicarbazone ligand. The characterization results of the complexes confirm the octahedral geometry of ruthenium atom with dibasic tridentate thiosemicarbazone ligands. All the complexes and ligand shows significant antibacterial activity. Comparatively, the ruthenium(II) complexes were shown higher activity. This clearly states that the coordination of thiosemicarbazone ligand to ruthenium atom modifies the biological properties of the ligand. All the complexes have higher growth inhibition activity against $E$. coli than the S. aureus.

\section{REFERENCES}

1. T. Lazarevic, A. Rilak and Z. D. Bugarcic, Eur. J. Med. Chem., 142, 8(2017), DOI:10.1016/j.ejmech.2017.04.007.

2. K. Sampath, K. Karthik, R. Sivahari, and P. Arunkumar, Rasayan J. Chem., 10, 4(2017), DOI: 10.7324/RJC.2017.1041922.

3. R. Arancibia, C. Quintana, C. Biot, M.E. Medina, S. Carrere-Kremer, L. Kremer and A. Hugo Klahn, Inorg. Chem. Commun., 55, 139(2015), DOI: 10.1039/C7DT04142J

4. M.A. Hussein, T.S. Guan, R.A. Haque, M.B. KhadeerAhamed and A.M.S. Abdul Majid, Polyhedron, 85, 93(2015), DOI: 10.3390/ijms160613023.

5. L.-W. Xue, X. Wang and G.-Q. Zhao, Synth. React. Inorg. Met.-Org. Nano-Metal Chem., 42, 1334(2012), DOI: 10.1080/15533174.2012.680139.

6. S. Gopinathan, I.R. Unny, S.S. Deshpande and C. Gopinathan, Ind. J. Chem. 25 A, 1015(1986).

7. P. Viswanathamurthi and K. Natarajan, Synth. React. Inorg. Met.-Org. Nano-Metal Chem., 36, 415(2006), DOI: 10.1080/15533170600732619

8. K. Natarajan and U. Agarwala, Inorg. Nucl. Chem. Letters, 14, 7(1978).

9. K. Sampath, M. Mohanraj and C. Jayabalakrishnan, Inorg. Nano-metal Chem., 47, 1049 (2017). DOI:10.1080/24701556.2017.1284089.

10. K. Sampath and C. Jayabalakrishnan, Synth. React. Inorg. Met.-Org. Nano-Metal Chem., 45, 1145(2015), DOI:10.1080/15533174.2013.862688.

11. A.A. Ahmed, S.A. BenGuzzi and O.M. Ahshad, Rasayan J. Chem., 2, 781(2009).

12. P. Sathyadevi, P. Krishnamoorthy, N.S.P. Bhuvanesh, P. Kalaiselvi, V. Vijaya Padma and N. Dharmaraj, Eur. J. Med. Chem., 55, 420(2012), DOI: 10.1016/j.ejmech.2012.08.001

13. A. Kanchanadevi, R. Ramesh and D. Semeril, Inorg. Chem. Commun., 56, 116(2015), DOI: 10.1016/j.inoche.2015.04.006.

14. K. Sampath, S. Sathiyaraj and C. Jayabalakrishnan, Spectrochim. Acta A, 105, 582(2013), DOI: 10.1016/j.saa.2012.12.064.

15. R.P. Paitandi, R.K. Gupta, R.S. Singh, G. Sharma, B. Koch and D.S. Pandey, Eur. J. Med. Chem., 84, 17(2014), DOI:10.1016/j.ejmech.2014.06.052.

16. R. Ramachandran, G. Prakash, P. Viswanathamurthi and J.G. Malecki, Inorg. Chim. Acta, 477, 122(2018), DOI: 10.1016/j.ica.2018.03.007.

17. S.A. Khan and A.M. Asiri, Steroids,124, 23(2017), DOI: 10.1016/j.steroids.2017.05.001.

18. H. Yildirim, E. Guler, M. Yavuz, N. Ozturk, P. KoseYaman, E. Subasi, E. Sahin and S. Timur, Mater. Sci. Eng. C Mater. Biol. Appl., 44, 1(2014), DOI: 10.1016/j.msec.2014.08.007.

[RJC-4099/2018] 